$9-1-2008$

\title{
Freedom for the Bulgarian nurses and a Palestinian doctor.
}

Lawrence Parish

Thomas Jefferson University

Follow this and additional works at: https://jdc.jefferson.edu/dcbfp

Part of the Dermatology Commons

Let us know how access to this document benefits you

\section{Recommended Citation}

Parish, Lawrence, "Freedom for the Bulgarian nurses and a Palestinian doctor." (2008).

Department of Dermatology and Cutaneous Biology Faculty Papers. Paper 25.

https://jdc.jefferson.edu/dcbfp/25

This Article is brought to you for free and open access by the Jefferson Digital Commons. The Jefferson Digital Commons is a service of Thomas Jefferson University's Center for Teaching and Learning (CTL). The Commons is a showcase for Jefferson books and journals, peer-reviewed scholarly publications, unique historical collections from the University archives, and teaching tools. The Jefferson Digital Commons allows researchers and interested readers anywhere in the world to learn about and keep up to date with Jefferson scholarship. This article has been accepted for inclusion in Department of Dermatology and Cutaneous Biology Faculty Papers by an authorized administrator of the Jefferson Digital Commons. For more information, please contact: JeffersonDigitalCommons@jefferson.edu. 


\section{As submitted to:}

\section{Clinical Dermatology}

And later published as:

Freedom for the Bulgarian Nurses and a Palestinian Doctor

Volume 26, Issue 5, p. 574.

Sept-October 2008

\section{DOI: 10.1016/j.clindermatol.2007.11.009}

Letter from the Editor

Edited by Stephen P. Stone, MD

\section{Freedom for the Bulgarian Nurses and a Palestinian Doctor}

On July 24, 2007, the five Bulgarian nurses and the Palestinian, unjustly accused of infecting Libyan children with the AIDS virus, were freed by the Libyan government. They had spent a tumultuous seven years in prison, much of the time on death row, having been accused of injecting the children with tainted blood they had brought with them. This was not only preposterous but also an impossibility as the particular strain of the AIDS virus had been found in Libya, two years prior. [1]

In the September-October 2005 issue of Clinics in Dermatology, Nikolai Tsankov, MD, $\mathrm{PhD}$ and Andrey Kehayov, MD called attention to this horrible situation. To these physicians, we are most appreciative that called the attention of our readers to this flagrant violation of humans rights. [2] In recognition of the help provided by our publication, The Bulgarian Medical Association presented the Honorary Sign of the Association to Lawrence Charles Parish, MD, Editor-in-Chief on behalf of the Editors and Editorial Board of Clinics in Dermatology on October 19, 2007 in Sofia, Bulgaria. We thank the authors of their contribution.

\section{References:}

[1] Butler D. Libyan ordeal ends: medics freed. Nature. 2007;448:398.

[2] Tsankov N, Kehayov A. Crisis in Libya: Doctor and nurses under death sentence. Clinics in Dermatology. 2005;23:527. 
reported by Lawrence Charles Parish, MD larryderm@yahoo.com 


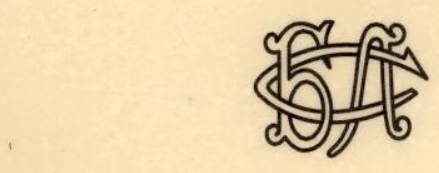

\section{CHARTER}

THE BULGARIAN MEDICAL ASSOCIATION

AWARDS

\section{Prof. Lawrence Parish}

with the

\section{Honotary Sign of the Association}

for the support provided in connection with the trial of the 5

Bulgarian nurses in Libya

19.10.2007

Sofia

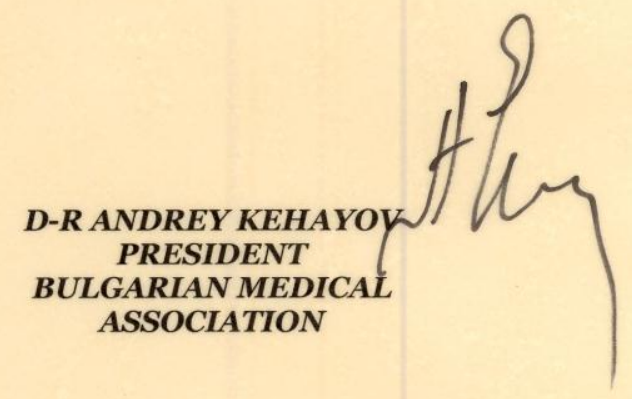




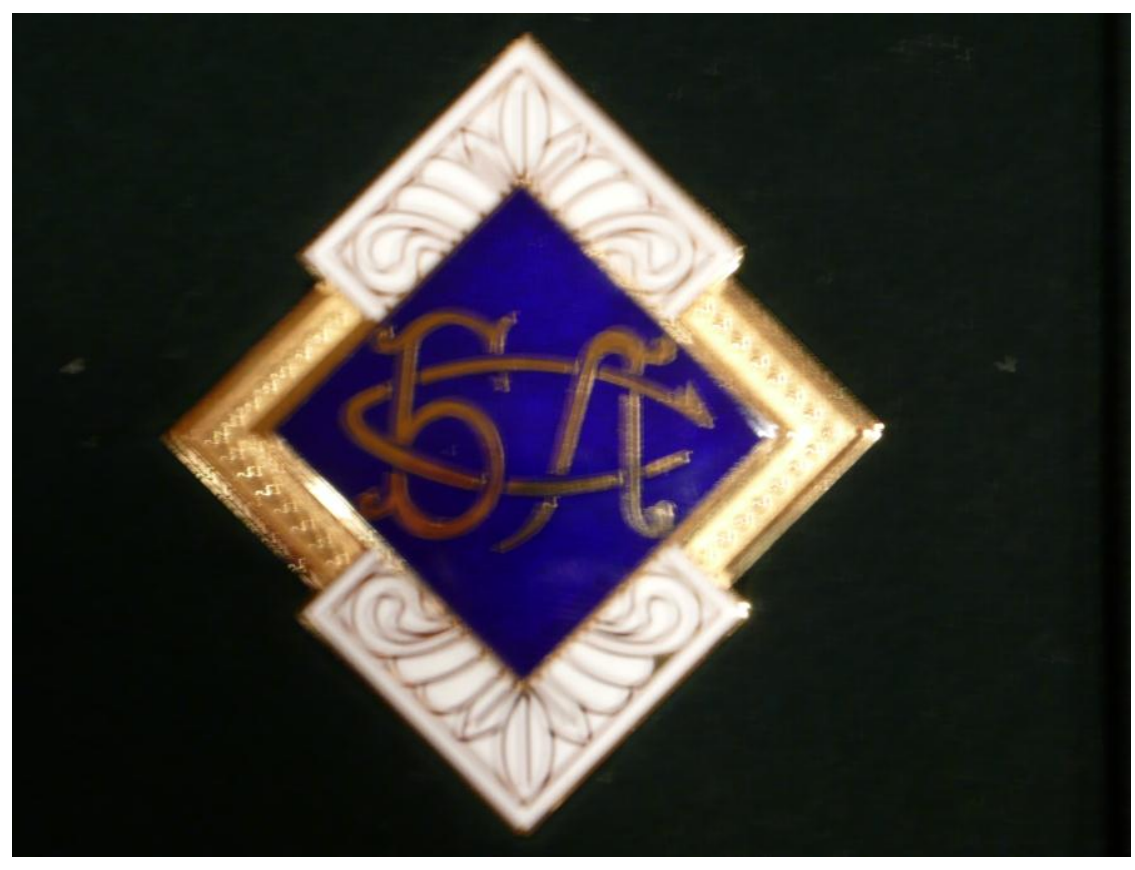

